\title{
RADIOCARBON DATING OF THE VUČEDOL CULTURE COMPLEX
}

\author{
ALEKSANDAR DURMAN \\ Faculty of Philosophy, Department of Archaeology, \\ Đure Salaja 3, 41000 Zagreb, Yugoslavia \\ BOGOMIL OBELIĆ \\ Ruđer Bošković Institute, POB 1016, 41001 Zagreb, \\ Croatia, Yugoslavia
}

\begin{abstract}
Radiocarbon dates of the Vučedol culture range from its earliest beginnings at Vučedol and Pivnica to its late phase at Vinkovci, Eastern Slavonia, Hrustovača, northwest Bosnia, Parte, Slovenia and Rudine, northwest Croatia. Recent ${ }^{14} \mathrm{C}$ analyses are discussed and compared to corresponding dates outside the scope of the Vučedol culture. Findings provide evidence for the expansion of the late Vučedol culture both in time and space.
\end{abstract}

\section{INTRODUCTION}

The Vučedol culture is a synonym for the late Copper Age of the Carpathian Valley and the western Balkans. It fills the span between the second wave of the Kurgan people expansion, according to Gimbutas (1973), in the central part of the Danube Basin and the start of the early Bronze Age, according to the central European chronology.

Previous dates of the Vučedol culture refer exclusively to the period of its existence in central Europe, when, in its late phase, this culture reached the northern region of the Carpathian Basin. We present results of recent ${ }^{14} \mathrm{C}$ analyses which provide evidence for the early existence and expansion of the late Vučedol culture. Our findings point to the need for more ${ }^{14} \mathrm{C}$ measurements to better understand the position of the late Vučedol in European prehistory.

The late phase of the Vučedol culture, particularly its Makó type, is closely related to the Bell Beaker culture, from which it is sometimes difficult to distinguish.

The Makó type of the Vučedol culture represents only its late phase and should not be identified with the general Vučedol culture. Since the Makó type also coincides with the late phase of the Corded Ware culture, it should be emphasized that only the late phase of the Vučedol culture can be considered parallel to the Corded Ware late phase. This situation is reinforced by the so-called low chronology (Milojčić, 1949; Dimitrijević, 1956, 1979), the result of skepticism towards ${ }^{14} \mathrm{C}$ dates. As a reflection of this attitude, Dimitrijević (1979) dated the Vučedol culture to 2150-1800 BC, based on typological associations.

Since 1984, systematic excavations have ben carried out at the Vineyard Streim site at Vučedol. The Ruder Bošković Institute measured $>20$ ${ }^{14} \mathrm{C}$ samples, 10 from the Vučedol layer. Only three of those have been taken into consideration in this paper because they belong to the oldest Vučedol period (while the remaining 7 correspond to the classical period of this culture). Two charcoal samples were also analyzed from the Vinkovci - Hotel site which belongs to the early phase of the Vinkovci culture, the immediate successor of the Vučedol culture at this site (Horvatinčić et al, in press). 
The Zagreb laboratory had earlier analyzed 3 samples from Ljubljansko Barje (Parte site) and 1 sample from Rudine, near Koprivnička Rijeka (Srdoč et al, 1981). All samples belong to the late phase of the Vučedol culture. Two samples from the Vučedol layers at Gomolava (Sirmium) (GrN-13167) and the Hrustovača cave (Bosnia) were analyzed (Grn-8011); another sample was dated from Hrustovača (Bln-564). The Berlin laboratory also analyzed a sample from the Pivnica site (northeastern Bosnia) (Dimitrijević, 1979). Results are listed in Table 1.

TABLE 1

${ }^{14} \mathrm{C}$ results of Vučedol and Corded Ware samples

\begin{tabular}{|c|c|c|c|c|}
\hline Site, phase & Provenience & Lab no. & $\begin{array}{l}{ }^{14} \mathrm{C} \text { age } \\
\text { (BP) }\end{array}$ & $\begin{array}{l}\text { Calibrated range } \\
\text { (BC) }\end{array}$ \\
\hline \multicolumn{5}{|c|}{ Vučedol culture, Yugoslavia } \\
\hline Vučedol & Pit 6/85 & Z-1637 & $4322 \pm 100$ & $3077-2787$ \\
\hline (Vineyard & Pit 2/85 & Z-1621 & $4314 \pm 100$ & $3040-2785$ \\
\hline Streim) & Pit $14 / 85$ & Z-1447 & $4286 \pm 120$ & $3040-2703$ \\
\hline Pivnica & & GrN-8010 & $4290 \pm 60$ & $3013-2788$ \\
\hline Gomolava & Phase IIIb/17 & GrN-13167 & $4210 \pm 60$ & $2910-2699$ \\
\hline \multirow[t]{2}{*}{ Hrustovača } & & GrN-8011 & $4165 \pm 35$ & $2881-2629$ \\
\hline & & BIN-564 & $4125 \pm 80$ & $2882-2581$ \\
\hline \multirow[t]{3}{*}{ Parte } & No. 16 & Z-539 & $3920 \pm 100$ & $2573-2290$ \\
\hline & No. 81 & $\mathrm{Z}-540$ & $4010 \pm 100$ & $2858-2460$ \\
\hline & No. 2 & Z-647 & $4010 \pm 100$ & $2858-2460$ \\
\hline \multirow[t]{2}{*}{ Vinkovci } & Hotel & $\mathrm{Z}-1817$ & $3809 \pm 138$ & $2470-2039$ \\
\hline & Hotel & Z-1818 & $3835 \pm 140$ & $2551-2046$ \\
\hline Rudine & & $\mathrm{Z}-722$ & $3750 \pm 110$ & $2340-2030$ \\
\hline \multicolumn{5}{|c|}{ Corded Ware culture } \\
\hline Csepel & Pit 2 & GrN-6900 & $3945 \pm 40$ & $2557-2458$ \\
\hline \multirow[t]{2}{*}{ (Hungary) } & Pit 3 & GrN-6901 & $3830 \pm 55$ & $2455-2200$ \\
\hline & & GrN-9231 & $3945 \pm 35$ & $2554-2459$ \\
\hline Vikletice & Grave 41 & GrN-9379 & $3940 \pm 35$ & $2552-2458$ \\
\hline \multirow[t]{2}{*}{ (Bohemia) } & Grave 119 & GrN-9481 & $3935 \pm 35$ & $2485-2457$ \\
\hline & Grave 58 & GrN-9482 & $3860 \pm 35$ & $2457-2290$ \\
\hline $\begin{array}{l}\text { Kesocha } \\
\text { (Poland) }\end{array}$ & Grave & K-1836 & $3880 \pm 100$ & $2554-2200$ \\
\hline $\begin{array}{l}\text { Miernow } \\
\text { (Poland) }\end{array}$ & $\begin{array}{l}\text { Barrow 2, } \\
\text { grave } 2\end{array}$ & K-1837 & $3960 \pm 100$ & $2590-2340$ \\
\hline $\begin{array}{l}\text { Krivine-Golovsk } \\
\text { (Byelorussia) }\end{array}$ & & GrN-5125 & $4270 \pm 40$ & $2918-2788$ \\
\hline Sitagroi & Phase Va & Bln- 877 & $4170 \pm 100$ & $2910-2590$ \\
\hline (Greece) & Phase Va & BM-652 & $3803 \pm 59$ & $2346-2143$ \\
\hline Ezero & Phase $\mathrm{I} / \mathrm{A}_{1}$ & Bln-725 & $4120 \pm 100$ & $2886-2506$ \\
\hline \multirow[t]{5}{*}{ (Bulgaria) } & Phase I/A 1 & Bln-726 & $4285 \pm 100$ & $3030-2707$ \\
\hline & Phase $\mathrm{I} / \mathrm{A}_{1}$ & Bln-727 & $4315 \pm 100$ & $3040-2785$ \\
\hline & Phase $\mathrm{I} / \mathrm{B}_{1}$ & Bln-429 & $4130 \pm 100$ & $2888-2510$ \\
\hline & Phase $\mathrm{I} / \mathrm{B}_{1}$ & Bln-428 & $4260 \pm 80$ & 2923-2706 \\
\hline & Phase $\mathrm{I} / \mathrm{B}_{1}$ & Bln-427 & $4365 \pm 80$ & $3095-2912$ \\
\hline
\end{tabular}




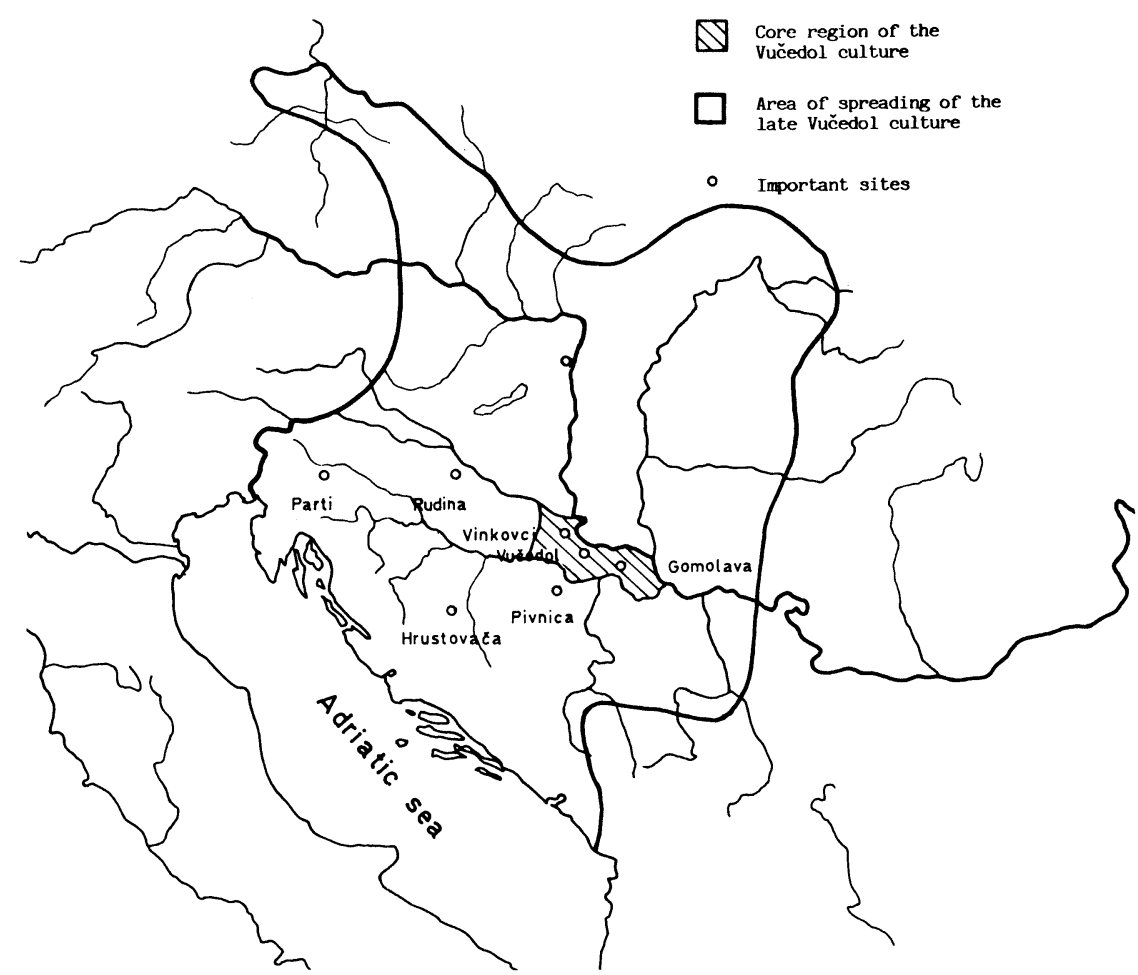

Fig 1. Map of the Vučedol culture expansion in its late phase

Prior to the recent excavations at Vučedol, only finds dating from the early classical phase $\left(B_{1}\right)$ were known. However, one sample taken from the Pivnica site belongs to the oldest (A) phase of the Vučedol culture. For example, a layer at Pivnica yielded early Vučedol pottery. ${ }^{14} \mathrm{C}$ dates representing the classical Vučedol culture are from Vučedol, Gomolava 3b, and, surprisingly, the Hrustovača cave (Table 1), the ceramic material of which is attributed to the late phase, so-called west Bosnian or Hrustovača type (Fig 1). Such evidence confirms that the zone of the early Vučedol culture, or its core region, extends from eastern Slavonia to northeastern Bosnia, expansion occurring later.

The late Vučedol is also documented by three ${ }^{14} \mathrm{C}$ analyses from the Parte site (Harej, 1978, 1981). Typologically, the ceramic material from this site is very similar to that of the late Vučedol at the Vinkovci Hotel site where remains of the early phase of the Vinkovci culture were also found. However, the Vučedol finds are still younger than those found at Parte. The Rudine site, near Koprivnička Rijeka (northwest Croatia), yielded considerably later dates, whereas the ceramic material is closer to the late Vučedol than to the Vinkovci culture (Table 1). Figure 1 shows the Vučedol culture expansion in its late phase. 


\section{Radiocarbon Measurements}

Most (13) of the samples were charcoal from waste pits, at Rudine near Koprivnička Rijeka (Srdoč et al, 1981), Vučedol and Vinkovci (Horvatinčić et $a l$, in press), or wooden fragments (3) of pile dwellings at Parte near Ljubljana (Srdoč et al, 1981).

Rootlets that penetrated the sample level were carefully removed. Samples were pretreated by boiling in $4 \% \mathrm{HCl}$ and $4 \%$ solution of $\mathrm{NaOH}$. Further procedure includes combustion in a stream of pure oxygen, catalytic hydrogenation of $\mathrm{CO}_{2}$ to $\mathrm{CH}_{4}$ and measurement in a proportional counter (Srdoč, Breyer \& Sliepčević, 1971). Data processing is done by computer and the results are stored in the Zagreb data base (Obelić, 1989). ${ }^{14} \mathrm{C}$ ages are calibrated according to a recent modification of Stuiver and Reimer's program $(1986,1987)$. Calibrated ages are presented both as extremes of $1 \sigma$ ranges and of the highest probability around the ${ }^{14} \mathrm{C}$ age (Table 1 ).

Results from Vineyard Streim (Z-1637: 4322 \pm 100 ; Z-1621: 4314 \pm 100 ;

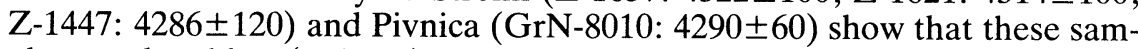
ples are the oldest (Table 1), which was confirmed by typological analysis of the ceramic material. Ceramics from Pit 6/1985 also yielded the oldest dates, and were associated with elements of the Kostolac and Cotofeni III cultures, similar to those from the Basarabi and Mecesu de Jos sites (Roman, 1977, pl 97).

The youngest ${ }^{14} \mathrm{C}$ dates in the core region of the Vučedol culture $(\mathrm{Z}$ 1817: $3809 \pm 140$; Z-1818: $3835 \pm 140$ ) were obtained from 2 samples from the Vinkovci Hotel site (Table 1), from a layer in which the Vučedol and the early Vinkovci cultures are combined. Thus, the Vučedol and the Vinkovci sites represent the maximum duration, ca 4322-3835 BP (Table 1), of the Vučedol culture in its core region (Fig 2).

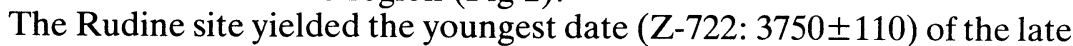
Vučedol expansion (Table 1). However, since only one sample was analyzed, we must view this result with reserve. Yet we would like to consider this site a kind of refuge of the late Vučedol culture, a detached enclave in post-Vučedol times.

Ceramic samples from Vučedol manifest many features of the Baden and Kostolac cultures, as well as the Late Neolithic Sopot culture. The relationships between the Vučedol and other contemporaneous cultures can best be observed at the Vinkovci Hotel site. In the late classical Vučedol phase $\left(\mathrm{B}_{2}\right)$ at Vinkovci, on the other hand, Corded Ware pottery is also found, whereas in the late phase (C), Bell Beaker ceramics are found along with Vinkovci and Corded Ware artifacts. Such similarities can also be observed at the Parte site at Ljubljansko Barje (Harej, 1978, 1981). This, obviously, does not mean that the Corded Ware culture occurred as late as the late Vučedol culture, but suggests that the mutual permeation of these two cultures began only after the Vučedol expansion to the north and east (Fig 2).

The results of the analyses of the Corded Ware samples from KrivineGolovsk, Byelorussian SSR (GrN-5125), Kesocha and Miernow, Poland (K1836, -1837) and Vikletice, Bohemia (GrN-9379, -9481, -9482) (Table 1) were also taken into consideration (Fig 2). 


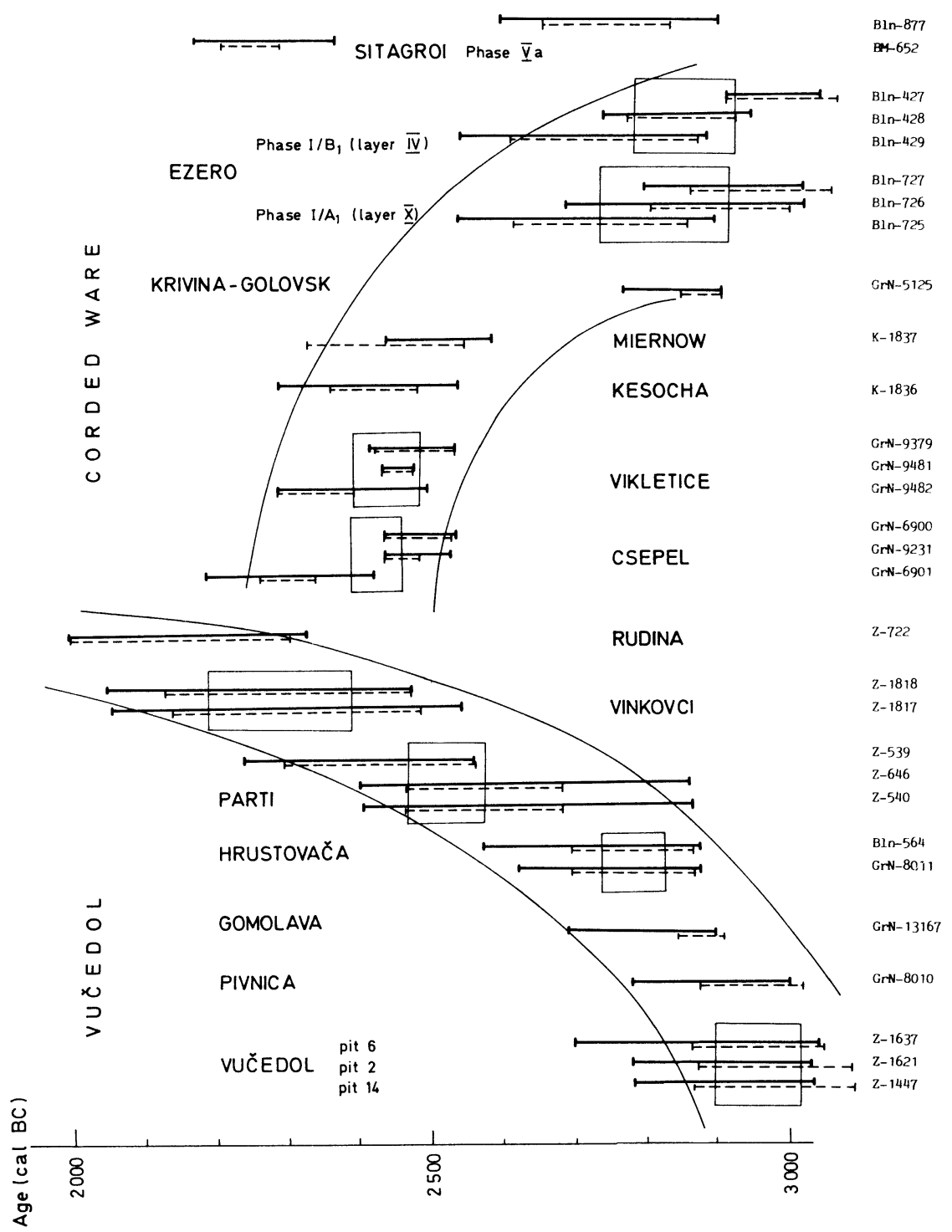

Fig 2. Chronology of the Vučedol culture sites. ${ }^{14} \mathrm{C}$ ages are calibrated according to Stuiver and Reimer (1986). Solid lines represent extremes of $1 \sigma$ ranges: dotted lines represent the highest possibility around the ${ }^{14} \mathrm{C}$ age (1 $\sigma$ range) as a function of time. Mean values of several measurements are framed in squares.

The horn shapes on Figure 2 represent two series of analyses which made it possible to determine the age ranges of the Corded Ware and Vučedol cultures and their territorial relationship. These two cultures came into direct contact only in the period of the late Vučedol culture, which coincided with the emergence of the Bell Beaker-Csepel culture in the central Danube. The Sitagroi site remained outside of the "horn shapes" on Figure 2 although 
in its Va layer the Vučedol pottery was found (Renfrew, 1971, p 276). This is due to the fact that 2 analyses from 2 different laboratories produced entirely different results.

Particularly interesting is the comparison of the Bell Beaker-Csepel group (GrN-6900, -6901, -9231) (Table 1) with the Parte and Vinkovci sites (Fig 2). These analyses support Neustupnýs (1984, p 109) conclusions that the development of cultures in the Carpathian basin at the end of the Eneolithic period can be divided into three time zones: 1) the latest phase of Vučedol represented by the Čaka group, 2) a post-Vučedol phase represented by Vinkovci in the south and by Bell Beakers in the Budapest region, and 3) early Nagyrév which is Early Bronze Age in central Europe.

To the south, the Vučedol culture shows phenomena related to the first layer at the Ezero site in Bulgaria (Georgiev, 1979) and the Va layer at Sitagroi. Ezero ceramics, and particularly finds of metal and molds (Horizons IVVI of the first layer) bear many similarities to the late phase of the Vučedol culture at Ljubljansko Barje, as well as with the pottery of the youngest Vučedol layer in Vinkovci (Durman, 1983). Renfrew (1971, p 276) places Sitagroi V in the Early Bronze Age of the Aegean (Early Helladic II and III). 2300-1800 or $1700 \mathrm{BC}$, which, in central Europe, goes through, and perhaps beyond Neustupný's "Late Eneolithic," with Corded Ware and Bell Beakers.

\section{CONCLUSIONS}

The results of ${ }^{14} \mathrm{C}$ analyses show that the Vučedol and Pivnica sites yielded the oldest finds of the Vučedol culture in its core region. The Corded Ware culture existed to the east of the Carpathian Mountains, from Byelorussia to Bulgaria, as early as the early phase of the Vučedol culture. Due to its radial expansion, the Vučedol culture came into direct contact with the Corded Ware and Bell Beaker cultures, which spread westwards.

\section{REFERENCES}

Dimitrijević, S, 1956, Prilog daljem upoznavanju vučedolske kulture: Opuscula Archaeol 1 Zagreb, p 5-56.

1979, Vučedolska kultura i vučedolski kulturni kompleks. Praistorija jugoslavenskih zemalja 3, Sarajevo, p 267-341

Durman, A 1983, Metalurgija vučedolskog kulturnog kompleksa: Opuscula Archaeol 8, Zagreb, $96 \mathrm{p}$

Georgiev, G, Merpert, N, Katinčarov, P and Dimitrov, D, eds, 1979, Ezero, ranobronzovato seliše: Balgarska akademija na naukite, Arheologičeski institut, Sofija, 547 p.

Gimbutas, M, 1973, The Beginning of the Bronze Age in Europe and the Indo-Europeans: 3500-2500 BC: Jour Indo-European Studies, v 1, no. 2, p 163-214.

Harej, Z, 1978, Kolišče v Partih pri Igu na Ljubljanskem Barju: Poročilo o raziskovanju paleolita, neolita in eneolita v Sloveniji VI, Ljubljana, p 61-82.

1981, Kolišče v Partih pri Igu na Ljubljanskem Barju: Poročilo o raziskovanju paleolita, neolita in eneolita v Sloveniji IX-X, Ljubljana, p 31-99.

Horvatinčić, N, Obelić, B, Srdoč, D, Durman, A, Benkö, L and Sliepčević A, in press, Radiocarbon and TL dating of the Eneolithic site Vučedol in East Croatia, Yugoslavia in Internatl symposium, Archaeology and ${ }^{14} \mathrm{C}$ 2nd, Proc: PACT

Milojčić, V, 1949, Chronologie der jüngeren Steinzeit Mittel und Südosteuropas, Berlin, p 94.

Neustupný, E, 1984, The Bell Beaker culture in east central Europe in L'age du cuivre Européen Civilisations á vases campaniformes: Paris, p 107-119 
Obelić, B, 1989, The radiocarbon data base at Ruđer Bošković Institute Radiocarbon Laboratory: Radiocarbon, this issue.

Renfrew, C, 1971, Sitagroi, radiocarbon and the prehistory of south-east Europe: Antiquity, XLV, p 275-282.

Roman, P, 1977, The Later Copper Age Cotofeni culture in south-east Europe: BAR, Suppl ser $32,122 \mathrm{p}$.

Srdoč, D, Breyer, B and Sliepčević, A, 1971, Ruđer Bošković Institute radiocarbon measurements I: Radiocarbon, $\mathrm{v} 13$, no. 1, 135-140.

Srdoč, D, Sliepčević, A, Obelić, B and Horvatinčić, N, 1981, Ruđer Bošković Institute Radiocarbon measurements VI: Radiocarbon, v 23, no. 3, p 410-421.

Stuiver, M and Reimer, P J, 1986, A computer program for radiocarbon age calibration in Stuiver, $\mathrm{M}$ and $\mathrm{Kra}, \mathrm{R} \mathrm{S}$, eds, Internatl ${ }^{14} \mathrm{C}$ conf 12 th Proc: Radiocarbon v 28, no, 2B, p 1022-1030.

1987, User's guide to the programs CALIB and DISPLAY Rev 2.1: Quaternary Isotope Lab, Univ Washington. 